\title{
THE STUDY OF THERMAL PROCESSES IN FISH\&PLANT SEMI-PRODUCTS
}

\author{
Nataliia Prytulska \\ Department of Commodity Sciences, Safety and Quality Management \\ Kyiv National University of Trade and Economics \\ 19 Kyoto str., Kyiv, Ukraine, 02156 \\ prytulska@knteu.kiev.ua \\ Dina Fedorova \\ Department of Technology and the Organization of Restaurant Business \\ Kyiv National University of Trade and Economics \\ 19 Kyoto str., Kyiv, Ukraine, 02156 \\ dina_fedorova@ukr.net \\ Maxim Lazarenko \\ Department of Molecular Physics \\ Kyiv National University Taras Shevchenko \\ 19 Kyoto str., Kyiv, Ukraine, 02156 \\ maxs@univ.kiev.ua

\section{Olena Vasylieva} \\ Department of technology and the organization of restaurant business \\ Kyiv National University of Trade and Economics \\ 19 Kyoto str., Kyiv, Ukraine, 02156 \\ vasuleva2015@ukr.net \\ Tatiana Yudina \\ Department of Technology and the organization of restaurant business \\ Kyiv National University of Trade and Economics \\ 19 Kyoto str., Kyiv, Ukraine, 02156 \\ olegdmu@rambler.ru
}

\begin{abstract}
The water-holding ability and forms of connection in fish\&plant semi-products were experimentally studied using derivatograph Q-1500 D by «MOM» of Paulik-Paulik-Erdey system (Hungry). Using the methods of thermogravimetry methods in experimental samples was synchronously measured the temperature (T), change of mass (TG), speed of temperature change (DTG) and change of thermal capacity (DTA). According to derivatograms the volume of the mass loss $(\Delta \mathrm{m})$ and derivative change of DGT mass of the studied sample at correspondent temperature were determined. The thermal resistance of samples was assessed by the methods of thermogravimetry (by admissible mass loss that takes place at certain temperature) and differential-thermal analysis (by thermal effects that attend the chemical transformations of macromolecules, which intensity depends on temperature).

According to the results of thermogravimetric and differential-thermal examination there was carried out the comparative characterization of the quantity of absorption- and capillary bound water in studied samples of fish\&plant semi-products and also determined the value of activation energy of water molecules at different temperatures of water removing. The dependence of DTG samples was divided in peaks using Gauss distribution. According to the analysis of DTG peaks the quantity of osmotic- and absorption-bound water was determined in the samples of minces, produced on the base of complex of raw and preliminary thermally processed muscular, connective and bone tissues of Azov goby (Neogobius melanostomus). The received results give a possibility to understand better the structural changes that take place in the process of drying of fish\&plant semi-products. They can be used for optimization of the process of drying of fish\&plant semi-products and prognostication of their technological behavior in the different food systems and at storage.

Keywords: thermogravimetric analysis, differential-thermal analysis, fish\&plant semi-products, Azov goby (Neogobius melanostomus), dehydration, capillary and absorbed moisture, activation energy.
\end{abstract}




\section{Introduction}

The great importance for food safety of the country is gained by technologies of complex and low-waste processing of accessible fish raw material. The small Azov goby Neogobius melanostomus is for today the one of most numerous and accessible by cost objects of the fishery in Ukraine. This type of fish raw material is a source of valuable and easily assimilated protein and its tissues - of bioaccessible calcium that determines the expedience of its complex processing for production of food in the segment of social nutrition $[1,2]$. The topical is an improvement of technologies and properties of health-improving food products on the base of fish and vegetable raw material, especially the dry polyfunctional semi-products on the base of complex of muscular, connective and bone tissues of Azov goby (Neogobius melanostomus) for the wide assortment of culinary products, bakery, snack products, concentrated sauces, dry breakfasts, dinner products, dry shaped products. The important contribution in the solution of fundamental problems of creation of technologies of dry products of vegetable and fish raw material was made by the studies of numerous scientists [3-10].

The process of dehydration of fish\&plant semi-products is the one of important stages that characterizes the quality of ready production and its economic effectiveness. The determination of the features of moisture status in fish\&plant semi-products on the base of raw and blanched Azov goby (gutted, headless) using the vegetable ingredients by the method of thermogravimetric analysis gives a possibility to ground the structural changes of the water, determine the dehydration duration and realize the influence on the food systems behavior at storage.

\section{Materials and Methods}

As the objects of research were used the freshly-prepared (native) model minces on the base of raw and blanched Azov goby, whole, glutted, headless using the functional vegetable ingredients and also the model minces of restored dry fish\&plant semi-products (powders) (Fig. 1).

The objects of research - the frozen, small (up to $10 \mathrm{~cm}$ ) Azov goby, produced by LLC "Azovfish" according to SST 15-25-98 "Small frozen fish. Technical conditions", freshly-prepared (native) model minces on the base of dry and blanched goby, whole, glutted, headless using wheat siftings and also comminuted dry fish\&plant semi-product (powder) on the base of model mince of Azov goby.

The preparation of raw material for the production of fish\&plant semi-products was carried out as following: model minces were prepared of the raw and blanched small Azov goby, whole, glutted, headless, twice comminuted on the whirligig with orifices diameter 5 and $2 \mathrm{~mm}$ with/without using the wheat siftings in quantity $15 \%$ of the raw material mass.

The small Azov goby, glutted, headless (with skin, bones and tail fin) underwent the steam-thermal processing at temperature $85-90{ }^{\circ} \mathrm{C}$ during $15 \cdot 60 \mathrm{~s}$, left on sieve during $7,2 \cdot 10^{3} \mathrm{~s}$ for draining of water and comminuted on whirligig with orifices diameter 5 and $2 \mathrm{~mm}$ - for minces without siftings and for minces with siftings - comminuted on whirligig with orifices diameter $5 \mathrm{~mm}$, wheat siftings were added, kept during $7,2 \cdot 10^{3} \mathrm{~s}$ for the swelling of hydrocolloids and stabilization of mass exchange (distribution of moisture) and once more comminuted on whirligig with orifices diameter $2 \mathrm{~mm}$.

The model mince E2 was dried in convective dryer at temperature $60{ }^{\circ} \mathrm{C}$, speed of movement of drying agent $1 \mathrm{~m} / \mathrm{s}$ and water content $10 \mathrm{~g} / \mathrm{kg}$ of dry air to the constant mass with further comminution during $40 \mathrm{~s}$ in ordinary comminutor of the hammer type into powder.

The control sample of model mince C1 was prepared of the blanched Azov goby, whole, glutted, headless, twice comminuted on the whirligig with orifices diameter 5 and $2 \mathrm{~mm}$; the control sample of mince $\mathrm{C} 2$ - of the raw Azov goby, whole, glutted headless, twice comminuted on the whirligig with orifices diameter 5 and $2 \mathrm{~mm}$; the experimental sample of mince E $1-$ of the blanched small Azov goby, whole, glutted, headless, twice comminuted on the whirligig with $15 \%$ of wheat siftings; the experimental sample of mince E 2 - on the base of dry fish\&plant semi-product, restored in the water (hydromodule 1:3), prepared of the blanched Azov goby, whole, glutted, headless, twice comminuted on the whirligig with adding $15 \%$ of wheat siftings. 


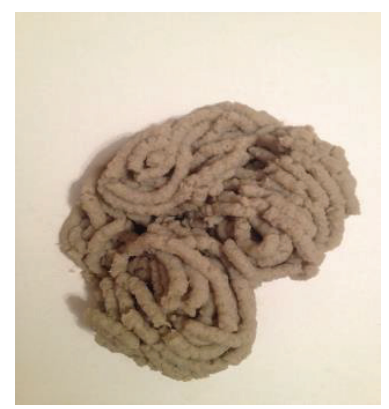

$a$

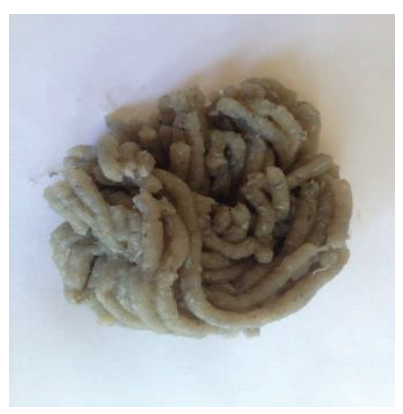

b

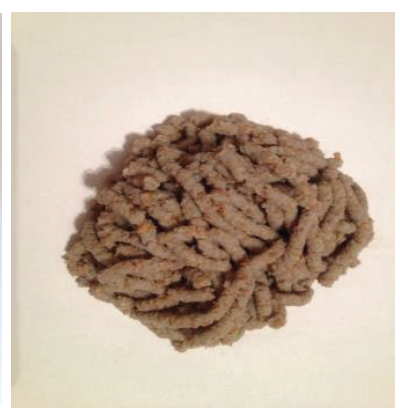

C

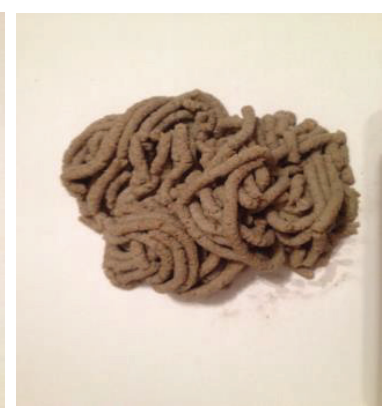

d

Fig. 1. The studied samples of fish\&plant semi-products: $a$ - control 1 (C 1); b - control 2 (C 2); $\mathrm{c}$ - experiment 1 (E 1); $d$-experiment 2 (E 2)

Thermogravimetric analysis was carried out using derivatograph Q-1500 D by «MOM» of Paulik-Paulik-Erdey system (Hungry) (Fig. 2).
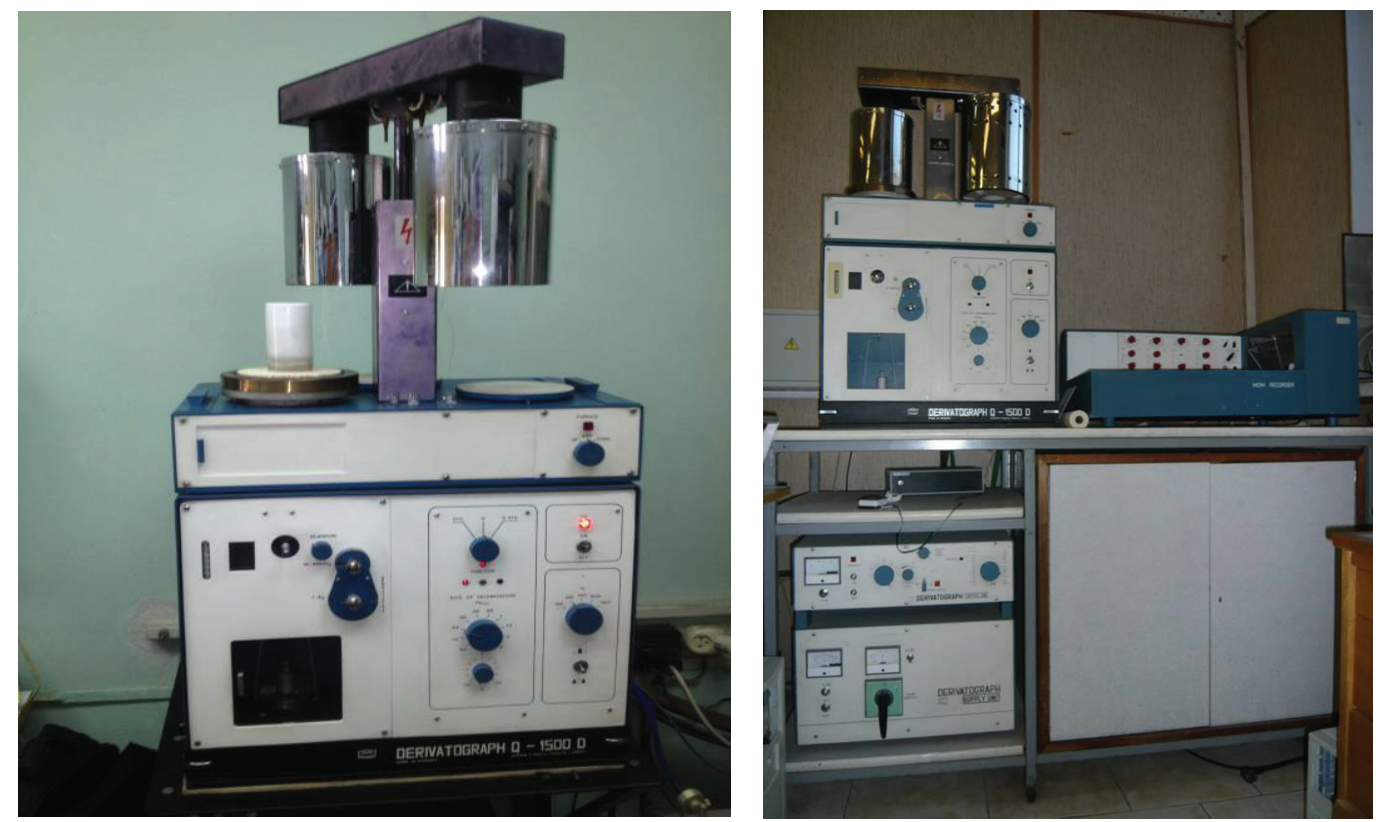

Fig. 2. Visualization of the measuring laboratory device derivatograph Q-1500 D

Derivatograph Q-1500 D - device for thermal analysis that allows synchronously register at the temperature change with given speed the temperature of substance (T), its mass (TG) and speed of its change (DTG). The analysis of TG is facilitated at synchronous registration of DTG curve and allows fully assess the processes that take place in experimental sample at thermal transformations. With the help of DTA can be determined the direction of change of enthalpy, connected with chemical reactions that take place in studied substance under the influence of temperature.

The differential thermal analysis (DTA) is based on registration of the difference of temperature of studied substance and inertial sample of comparison at their synchronous heating or cooling. At the temperature change in sample can take place the processes with enthalpy change, as for example, melting, rebuilding of crystal structure, evaporation, dehydration reaction, dissociation or disintegration, oxidation or restoration. Such transformations are attended with absorption or discharge of heat, and due to that the temperature of sample and standard become differ. This method can fix even little changes of the sample temperature due to the device construction and namely to the fact that the registering thermal couples from sample and standard are directed towards each other. 
Experimental signal from two cells (Fig. 3, S and R) is measured at the same time. Because the cells are constructed maximally symmetrically, all processes, connected with heat transfer, that do not belong directly to the sample influence them similarly and can be excluded from the experiment by the subtraction of signal of the comparison cell from the signal of the cell with sample.
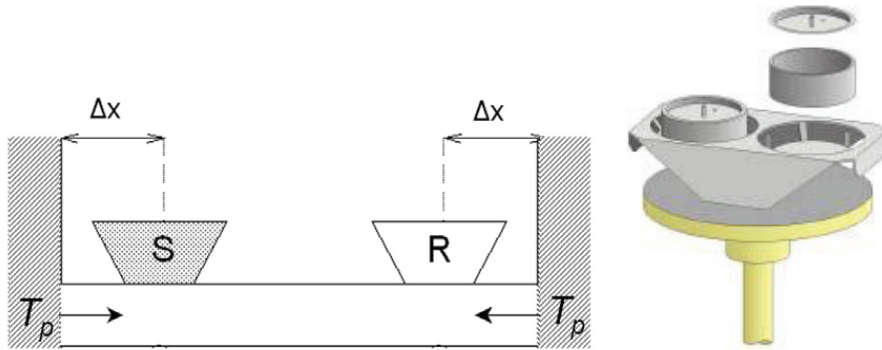

Fig. 3. The scheme and visualization of measuring cell of differential thermal analysis: $\mathrm{TP}$ - temperature of heater

The derivatograph is successfully used for the study of food products, especially for determination of water content in food systems (both bound and crystal ones), for determination of types of reactions (exo- or endothermal) and so on [11, 12].

The study of water-holding ability of fish\&plant semi-products was carried out using derivatograph, where the temperature (T), mass change (TG), mass change speed (DTG) and thermal capacity change (DTA) were synchronously measured in the experimental sample. According to derivatograms the volume of the mass loss $(\Delta \mathrm{m})$ and derivative change of DGT mass of the studied sample were determined at correspondent temperature. It can be assumed, that the mass loss of the sample is connected with the evaporation moisture that is in the different states in the sample. That is why the dependence of DTG was divided in peaks using Gauss distribution (Fig. 4).

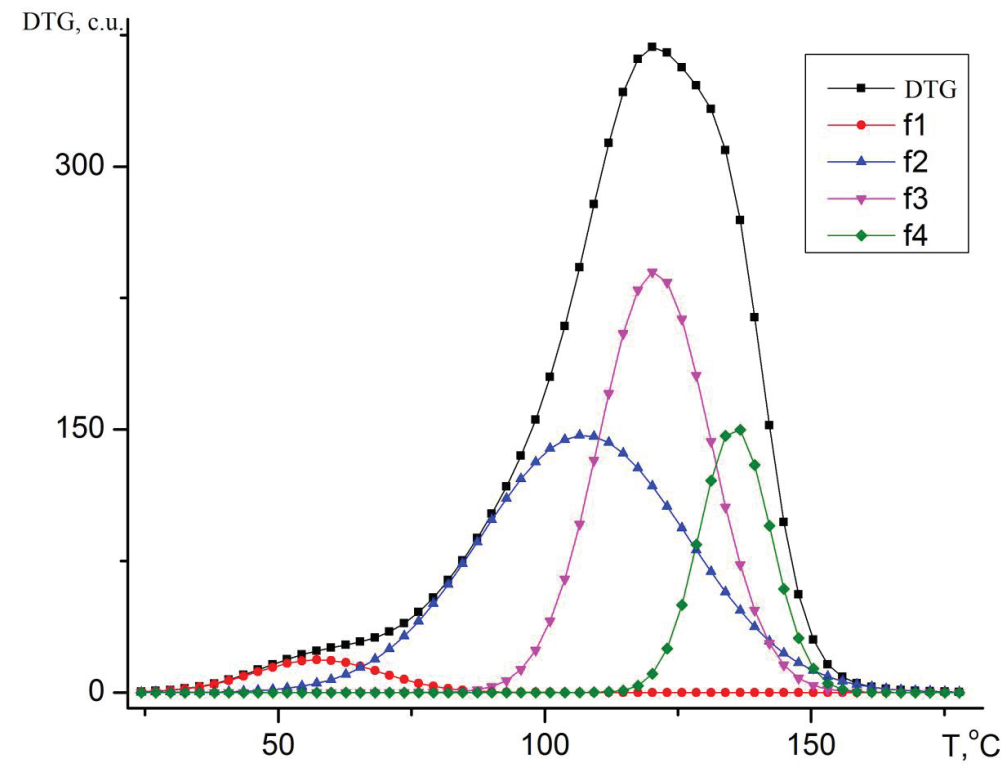

Fig. 4. Approximation of DTG dependence for E1 sample using Gauss distribution in four peaks

The DTG dependence for each of studied samples can be optimally described by the presence of four peaks. The first peak $\left(f_{1}\right)$ is connected with evaporation of moisture of physicalmechanical bind - capillary and butt that is in the rough macropores of the body, the other $\left(\mathrm{f}_{2}\right)$ - of capillary bound moisture of micropores and partially osmotic-bound moisture. The third peak $\left(\mathrm{f}_{3}\right)$ is connected with evaporation of moisture of physical-chemical bind - osmotic and adsorbed mois- 
ture - the moisture of polymolecular and monomolecular hydrate layers on internal and external surfaces of capillary-porous body of the fish and fish\&plant minces (hydrate layers around the hydrocolloid molecules - protein molecules of muscular, connective and bone tissues of fish raw material and polysaccharide molecules of siftings, first of all hemicelluloses and cellulose). The forth peak $\left(f_{4}\right)$ is a result of thermal oxidative destruction of the sample. The water in hydrate coat is bound with the protein molecules of fish and hemicelluloses molecules by hydrogen binds that are broken at heating.

In the data of differential-thermal analysis was demonstrated that the third peak (f3) is connected with water dehydration from hydrate layers around hydrocolloid molecules. The method of calculation of kinetic parameters of dehydration process such as energy of E activation and preexponential factor $\left(\mathrm{k}_{0}\right)$, are described in the work [11]. The kinetic equation of desorption process can be written as following:

$$
\mathrm{d} \Theta / \mathrm{dt}=-\mathrm{k} \Theta^{\mathrm{n}} ; \mathrm{k}=(-\mathrm{d} \Theta / \mathrm{dt}) / \Theta^{\mathrm{n}} .
$$

The degree of covering of hydrocolloid molecules by the water ones $(\Theta)$ changes from 1 (for initial material) to 0 (all water is dehydrated). The order of reaction (n) - whole number from 1 to 3 , it is assumed, that it is known from experiment. The reaction speed constant $(\mathrm{k})$ can be written as following:

$$
\mathrm{k}=\mathrm{k}_{0} \exp (-\mathrm{E} / \mathrm{RT})
$$

where $\mathrm{R}$ - universal gas constant. $\mathrm{E}$ is taken in this approximation as a constant that means the equivalence of all hydration centers of the hydrocolloid molecules surface. Putting the equation (1) in equation (2) and finding the logarithm we receive:

$$
\ln \mathrm{k}=\ln [(-\mathrm{d \Theta} / \mathrm{dt}) / \Theta \mathrm{n}]=\ln \mathrm{k}_{0}-\mathrm{E} / \mathrm{RT} \text {. }
$$

Taking into account the initial conditions $\Theta_{\mathrm{t}=0}=1, \Theta_{\mathrm{t}=\infty}=0$ and carrying out of experiment at the stable speed of heating $(\beta)$, that is the linear dependence of the temperature on time

$$
\mathrm{T}(\mathrm{t})=\mathrm{T}_{0}+\beta \mathrm{t}
$$

The following expressions can be written:

$$
\Theta(\mathrm{t})=\mathrm{S}_{\mathrm{T}} / \mathrm{S}_{0} ;-\mathrm{d} \Theta / \mathrm{dt}=\beta \mathrm{f}_{3} / \mathrm{S}_{0},
$$

where $\mathrm{S}_{0}$ and $\mathrm{S}_{\mathrm{T}}$ - according to the area on $\mathrm{f} 3$ graph below the whole peak and part of peak from $\mathrm{T}$ to $\infty$.

$$
\mathrm{s}_{\mathrm{T}}=\int_{\mathrm{T}}^{\infty} \mathrm{f}_{3} \mathrm{dT}, \mathrm{s}_{0}=\int_{0}^{\infty} \mathrm{f}_{3} \mathrm{dT} .
$$

If all assumptions, put in this method, are correct and the order of reaction $\mathrm{n}$ is chosen correctly, the dependence $\ln \left[(-\mathrm{d} \Theta / \mathrm{dt}) / \Theta_{\mathrm{n}}\right]$ on reversed temperature (equation (3)) is linear in whole temperature interval. Having the experimental values $f_{3}$ and $\beta$, according to expressions (5), (6) the $\Theta$ and $\mathrm{d} \Theta / \mathrm{dt}$ are received, the parameters of non-isometric kinetics $\mathrm{k}_{0}$ and $\mathrm{E}$ are calculated from the equation (3).

The advantage of aforesaid method is the use of whole experimental data set, including the high-temperature part of thermogram that is especially important at determination of order n, establishing of reaction mechanism and model adequacy.

From the constructed dependencies $\ln \left[(-\mathrm{d} \Theta / \mathrm{dt}) / \Theta_{\mathrm{n}}\right]$ from reversed temperature for studied samples it can be seen (Fig. 5), that the dependence takes the linear form at $n=2$. 


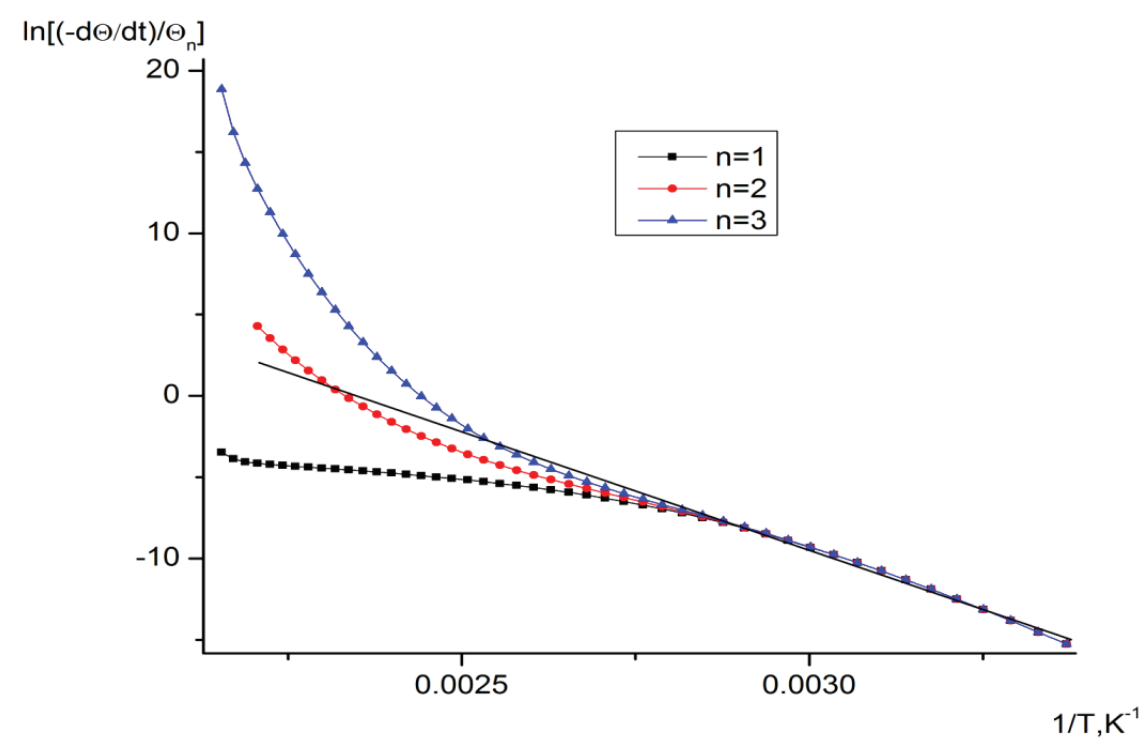

Fig. 5. The dependencies $\ln [(-\mathrm{d} \Theta / \mathrm{dt}) / \Theta n]$ from the reversed temperature

According to aforesaid method, the activation energies (E) and pre-exponential factors $\left(\mathrm{k}_{0}\right)$ of experimental samples were calculated.

\section{Results and their discussion}

The thermogravimetric indices were determined and differential-thermal analysis of experimental samples was carried out on the base of raw and blanched Azov goby, whole, glutted, headless using the vegetable ingredients, especially the wheat siftings.

The dependencies of relative change of mass $\Delta \mathrm{m} / \mathrm{m}_{0}$ and derivative change of mass DGT from the temperature were received for the different samples of fish\&plant semi-products. DTG dependence that characterizes the speed of mass change in experimental samples was divided in peaks using Gauss distribution. DTG dependence for each of studied samples can be optimally described by the presence of four peaks with maximums in temperature diapasons: $\mathrm{T}_{\mathrm{m} 1}-$ from 57 to $63{ }^{\circ} \mathrm{C}, \mathrm{T}_{\mathrm{m} 2}$ - from 102 to $110^{\circ} \mathrm{C}, \mathrm{T}_{\mathrm{m} 3}$ - from 119 to $122{ }^{\circ} \mathrm{C}, \mathrm{T}_{\mathrm{m} 4}$ - from 132 to $136{ }^{\circ} \mathrm{C}$.

According to the data of calculation of conventional energy of activation of the model fish and fish\&plant minces was established the presence of differences in its values for the same object at different temperature of bound water removal. It is explained by both processes of tissues deformation, proteins denaturation that lead to the changes of active centers number and decrease of the degree of polar, apolar and volume hydration of protein molecules of minces and soluble polysaccharides of wheat siftings - cellulose, hemicelluloses, pectin substances.

It was elucidated, that the conventional activation energy of preliminary thermally processed mince at temperature $102{ }^{\circ} \mathrm{C}\left(\mathrm{f}_{2}\right)$ exceeded by $6,3 \%$ the correspondent value for mince of native fish raw material. The bind energy in $\mathrm{f}_{2}$ for the sample of blanched fish raw material is higher comparing with the sample of native mince as the result of more complicated process of release of molecules of bound water of the volume protein hydration (especially, capillary bound water of micropores and osmotic-bound water) from the ordered structures of protein denatured molecules. So, the preliminary hydrothermal processing of the fish raw material leads to the partial loss of free water and certain increase of faintly bound water. It takes place as a result of watering of the fish proteins, first of all, myofibrillar muscular proteins of fish and also as a result of glutinization of collagen of connective tissue and ossein - of bone tissue of the fish raw material.

But in the next endothermal peak $\mathrm{f}_{3}$ (at temperature $119^{\circ} \mathrm{C}$ ) conventional activation energy of sample of mince of the native fish raw material significantly exceeded the value for thermally processed mince - by $25,6 \%$. It testifies to the more part of bound water in the samples of mince of the native fish raw material. It can be explained by the presence of active phase of conformational process denaturation of proteins of the complex of raw tissues of Azov goby in temperature peak $\mathrm{f}_{3}$ 
that is attended by the significant decrease of their dehydration degree and discharge of essential part of bound water. It is known, that the thermal effectiveness of convective-conductive drying of animal and vegetable tissues increases according to the decrease of water that can be bound by them $[13,14]$. The presence of exothermal denaturation process can influence the decrease of thermal effectiveness of drying of the native tissues of fish raw material because of possible lowering of their thermal physical properties and intensity of heat exchange that needs the additional studies as to determination of specific thermal capacity of tissues and heat of water evaporation.

It was experimentally established, that the experimental samples of model minces loose the less quantity of water by temperature zones as opposite to the control ones that testifies to the less content of free water in them. Such difference as to the mass loss by the mince samples in this period of time can be explained by the difference in the quantity of preliminary absorbed water (water content at the beginning of process) and also by the influence of vegetable components. At the expense of high water-binding properties (content of hydrophilic functional groups) and large specific surface, the vegetable components raise the binding energy of water in the product. It can be foreseen, that the introduction to the content of fish mince of powder-like dispersions - flour, starches, siftings and food shots $(50<\mathrm{r}<500)$ that have the large specific surface and correspondingly the high ability to absorbing water leads to the transfer of water, contained in the fish mince without additives in free state (bound by physical-mechanical forms of binds) into the bound state. It must objectively result in the increase of binding heat, increase of viscosity of disperse medium meshes and correspondingly in the strengthening of product structure.

Experimental data about the conventional activation energy of experimental samples allowed confirm this assumption. Really, for the peak $\mathrm{f}_{3}$, for which is typical the discharge of essential part of water from hydrate coats of soluble substances, the experimental samples of minces with vegetable raw material had the high values of conventional activation energy that exceeded the correspondent values for the control preliminary thermally processed mince without vegetable additives. It can be connected with the decrease of hydration degree of soluble polysaccharides of the vegetable component of experimental sample in this period as a result of partial removal of the water from hydrate coats.

Taking into account the given results it is correctly to say about the increase of the bound water and holding of the large quantity of bound water in experimental samples E1 and E2 by system. It takes place due to the increase of specific surface of its dispersed structure at the use of powder-like vegetable raw material and also creation of hydration binds by siftings polysaccharides that contain hemicelluloses, cellulose, lignin, pectin substances. Probably, at introduction into the content of fish mince of powder-like fine-dyspersated vegetable raw material such as wheat siftings take place the increase of moistening heat. It leads to the fact that the part of physical-mechanical moisture is transferred into physical-chemical - in average $6,9 \%$ of free moisture of control fish mince (C1) is bound by the additive in experiment E1 and 13,5 \% - by the complex of vegetable components in experimental sample E2. Such system needs more energy or higher temperatures for water removal that is proved by experimental data of conventional activation energy of these samples for peak $f_{3}$.

For the peak $\mathrm{f}_{2}$, for which is typical the discharge of faintly bound water - capillary and partially osmotic-bound water, the experimental samples of minces with vegetable raw material had the values of conventional activation energy, lower than the correspondent values for minces without vegetable additives.

The received experimental data testify to the fact that in experimental samples of fish minces with vegetable raw material is held less mechanically bound water that is retained by osmotic-diffuse forces of the capillary-porous body of fish\&plant semi-products and more bound water of hydrate layers around the molecules of sifting polysaccharides. At that the humidity of experimental systems and the content of free water in them decrease and the water content of hydration and moistening increases. Thus, the use of wheat siftings a bit increases the quantity of bound water in the structure of fish minces as a result of increase of the number of accessible hydroxyl group and formation of macroporous structure that conditions the raise of its hydrophilicity. Such fish\&plants semi-products will easily absorb or give away the capillary bound water depending on the change of external conditions. 
The offered hypotheses as to the mechanism of influence of vegetable raw material on the properties of fish\&plant semi-products on the base of raw and blanches tissues of Azov goby with wheat siftings can be qualitatively grounded at the comparison of the study of energy of bind of water with product, received by isotherms of sorption-desorption and also general and differential porosity of the control and experimental samples. It needs the additional studies.

\section{Conclusions}

According to the results of thermogravimetric and differentia-thermal studies, there was carried out the comparative characteristic of quantity of absorption- and capillary bound moisture in experimental samples of fish\&plants semi-products and also determined the value of activation energy of water molecules at the different temperatures of moisture removal. It was established, that the binding energy of absorption-bound moisture of fish\&plant semi-products depends on preliminary hydrothermal processing of fish raw material and use of vegetable raw material. According to the data of calculation of conventional activation energy of the model fish and fish\&plant minces it was established, that there is a difference between its values for the same objects at the different temperatures of the bound water removal. It was experimentally established, that the influence of vegetable raw material on the raise of activation energy of water molecules for experimental fish\&plant semi-products is less significant than the use of native fish raw material. The experimental data prove that the preliminary hydrothermal processing of complex of muscular, connective and bone tissues of Azov goby leads to the decrease of quantity of absorption-bound moisture.

The received results of the study give a possibility to understand better the structural changes that take place in the process of drying of fish\&plant semi-products. They can be used for optimization of the process of drying of fish\&plant semi-products and prognostication of their technological behavior in the different food systems and at storage. For the solution of optimization problem of drying of fish\&plant semi-products it is necessary to determine the Rebinder and Kosovich criteria, according to differential microcalorimetry that is the next stage of scientific study.

\section{References}

[1] Fedorova, D. Kuzmenko, Yu. (2015). Biollogichna cinnist rybo-roslinnyh napivfabrykativ na osnovi kompleksnogo pereroblenniia bychka azovskogo. Tovary i rynki, 2, 85-97.

[2] Prytulska, N., Fedorova, D., Bondarenko, Y. (2015). Konceptualni zasady formuvannya systemy socialnogo kharchuvannya v Ukrayini. Tovary i rynki, 1, 5-17.

[3] Abramova, L. S. (2005). Polikomponentnyie produkty pitaniia na osnove rybnogo syra. Moscow: VNIRO, 175.

[4] Kasyanov, G. I., Semenov, G. V., Grytzkyh, V. A., Troyanova, T. L. (2004). Sushka syrya i proizvodstvo suhih zavtrakov. Moscow: Mart, 160.

[5] Pogoshyh M. I., Potapov, V. O., Tsurkan, M. M. (2008). Tehnologii asushinnii aharchovoi syrovyny. Kharkiv: KhDUKhT, 229.

[6] Bonaui, C., Dumoulin, E., Raoult-Wack, A.-L., Berk, Z., Bimbenet, J. J., Courtois, F., Vasseur, J. (1996). Food Drying and Dewatering. Drying Technology, 14 (9), 2135-2170. doi: 10.1080/07373939608917199

[7] Elleuch, M., Bedigian, D., Roiseux, O., Besbes, S., Blecker, C., Attia, H. (2011). Dietary fibre and fibre-rich by-products of food processing: Characterisation, technological functionality and commercial applications: A review. Food Chemistry, 124 (2), 411-421. doi: 10.1016/j.foodchem.2010.06.077

[8] Schelvis, R., Borderias, A., Mierke-Klemeyer, S., Diaz-Rubio, M., Saura-Calixto, F., Luten, J., Careche, M. (2008). Developing functional seafood products. Improving Seafood Products for the Consumer, 331-362. doi: 10.1201/9781439833018.ch17

[9] Borderías, A. J., Sánchez-Alonso, I., Pérez-Mateos, M. (2005). New applications of fibres in foods: Addition to fishery products. Trends in Food Science and Technology, 16( 10), 458-465. doi: 10.1016/ j.tifs.2005.03.011

[10] Abdel-Moemin, A. R. (2015). Healthy cookies from cooked fish bones. Food Bioscience, 12, 114-121. doi: 10.1016/j.fbio.2015.09.003

[11] Pichkur, V. Ya., Lazarenko, M. M., Alekseev, O. M., Kovbasa, V. M., Lazarenko, M. V. (2015). Thermogravimetric research of the extruded and native types of starch. Eastern-European Journal of Enterprise Technologies, 1 (6 (73)), 52-56. doi: 10.15587/1729-4061.2015.33116 
[12] Dorohovich, V. V., Lazarenko, N. P. (2008). Doslidshenniia teplomasoobminnykh protsesiv, shcho vidbuvayut'sya pry vypikanni keksu na laktytoli. Khlibopekar i kondyter, 9, 21-23.

[13] Snyezhkin, Yu. F., Mykhaylyk, V. A., Dmytrenko, N. V. (2011). Dynamika zminy stanu vody v parenkhimnykh tkanynakh roslyn pry sushinni. Promyshlennaya teplotekhnyka, 33 (2), 35-40.

[14] Potapov, V. A. (2009). Kynetyka sushky: analyz y upravlenye protsessom. Kharkiv: KhGUPT, 250.

\title{
THE STUDY OF THE METHOD OF FIGHT AGAINST FORMATION OF POLARIZING LAYER AT THE PROCESS OF ULTRAFILTRATION CONCENTRATION OF THE SKIM MILK
}

\author{
Gregoriy Deynichenko \\ Department of Equipment Food and Hospitality Industry them. Belaeva \\ Kharkiv State University of Food Technology and Trade \\ 333 Klochkovskaya str., Kharkiv, Ukraine, 61051 \\ DeynichenkoGV@rambler.ru \\ Vasyl Guzenko \\ Department of Equipment Food and Hospitality Industry them. Belaeva \\ Kharkiv State University of Food Technology and Trade \\ 333 Klochkovskaya str., Kharkiv, Ukraine, 61051 \\ Peresada_7@mail.ru \\ Oleg Udovenko \\ PhD, Associate Professor \\ Department of General Engineering Disciplines and Equipment
}

Donetsk National University of Economics and Trade named after Mykhailo Tugan-Baranovsky 16 Ostrowski str., Kryvyi Rih, Ukraine, 50005

Udoleg@mail.ru

Aleksandr Omelchenko

PhD, Associate Professor

Department of General Engineering Disciplines and Equipment

Donetsk National University of Economics and Trade named after Mykhailo Tugan-Baranovsky

16 Ostrowski str., Kryvyi Rih, Ukraine, 50005

omelchenko84@ukr.net

Olga Melnik

PhD, Associate Professor

Department of General Engineering Disciplines and Equipment

Donetsk National University of Economics and Trade named after Mykhailo Tugan-Baranovsky

16 Ostrowski str., Kryvyi Rih, Ukraine, 50005

melnikolgaevgenivna@ukr.net

\footnotetext{
Abstract

The description of experimental set and the method of processing of the results of the study of the method of fight against formation of polarizing layer in the process of ultrafiltration concentration of skim milk raw material were presented. The results of experimental studies relative to the sparging method application for the prevention of polarizing layer in the process of membrane processing of the skim milk and its influence on the capacity of ultrafiltration membranes were offered. The mathematical models were constructed on the base of regressive equations of factorial experiment using the method of the raw material sparging above the membrane surface for selection of technological parameters of the process of ultrafiltration concentration of the skim milk. The ra-
} 